\title{
Problems of the irrigation system in the Turpan Basin of China
}

\author{
T. Nagasawa, T. Yamamoto \& A. Jalaldin \\ Graduate School of Agriculture, Hokkaido University, Japan
}

\begin{abstract}
The water resources of Turphan are composed of snow and glaciers from the Tian Shang Mountains. People in Turphan have continued with a consolidated agriculture method since old times, depending on traditional channels and Kareez (underground conduits). In recent years, arable land has increased with the population and the demands of the irrigated water have increased abruptly for the assurance of productivity. Traditional systems of irrigation could not supply the essential water to the extended arable land, so dams and wells have been constructed for irrigation. The construction of large scale reservoirs, canals and wells enabled the enlargement of the irrigated area and an increase in the production of agricultural products. But, the excessive irrigation caused an increase in the evapotranspiration and salinization. In conditions like this, the extensive arable land has progressed to desertification and abandonment. The more traditional systems of irrigation have been largely ignored because of the interference problems caused by various facilities that have decreased the use of traditional Kareez irrigation systems. The potentiality of water resources development is comparatively small, judging from the present condition of water use in Turphan, because the developed water resources must be utilized effectively and strong measures must be taken to save irrigation. The management of irrigation systems must be intensified, the new technology of irrigation must be popularized and the efforts of saving water must be made for the irrigation system
\end{abstract}

Keywords: Kareez, irrigation, Turpan basin, arid area.

\section{Introduction}

In an arid area, stable agricultural production depends heavily on irrigation. Irrigation systems consist of intakes, irrigation/discharge canals and the irrigated 
farmland, and their efficient operation requires specialized management. Most of the water used in Turpan, a city in the Xinjiang Uygur Autonomous Region of northwestern China, is underground water recharged by ice and snowmelt in the Tian Shan Mountains. The people here have long engaged in intensive farming, relying on traditional irrigation canals and underground conduits called Kareez.

The area under cultivation here has expanded with population increases, which has caused a rapid increase in demand for irrigation water. Because traditional irrigation systems did not provide sufficient water for the greater area under cultivation, irrigation dams and wells were constructed. Although largescale reservoirs, canals and wells have helped to increase the irrigated area and the agricultural output, the expansion of the irrigation system has promoted evapotranspiration and has accelerated salt accumulation. In light of this, many farm plots have been devastated and abandoned. Furthermore, interference between the various irritation facilities has decreased the use of traditional Kareez irrigation.

This paper examines the relationship between water resources and irrigation farming in an arid area and confirms the necessity of local irrigation management in achieving sustainable development.

\section{Study area and method}

Turpan, a city with the administrative status of a prefecture, is in the eastern part of the Xinjiang Uygur Autonomous Region, between the north latitudes of $42^{\circ} 15^{\prime} 10^{\prime \prime}$ and $43^{\circ} 35^{\prime} 00^{\prime \prime}$ and the east longitudes of $88^{\circ} 29^{\prime} 28^{\prime \prime}$ and $89^{\circ} 54^{\prime} 33^{\prime \prime}$. The city lies in a basin that is bordered to the north by the Tian Shan Mountains (approx. 4,000 m elev.) and to the south by the Qollok Mountains (approx. 1,500 m elev.). The Huoyan Shan Mountains run east-west through the center of the basin.

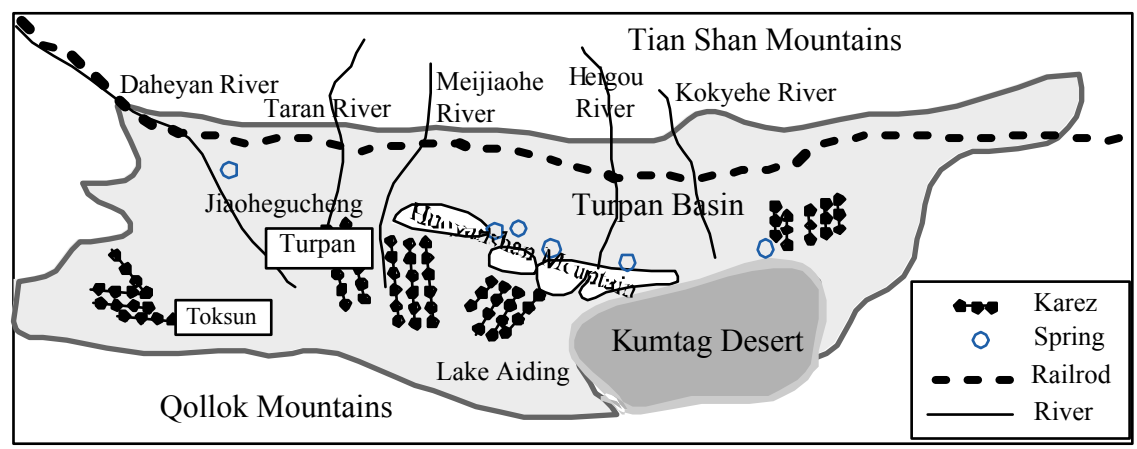

Figure 1: Outline of investigation area.

Mountains and plains respectively account for $21.8 \%$ and $78.2 \%$ of Turpan's area $\left(3,275 \mathrm{~km}^{2}\right.$ and $11,758 \mathrm{~km}^{2}$ out of $\left.15,033 \mathrm{~km}^{2}\right)$. The topography is 
characterized by an incline from the northern Tian Shan Mountains $(4,000 \mathrm{~m})$ to the southern Aiding Lake (-154 m) (Figure 2).

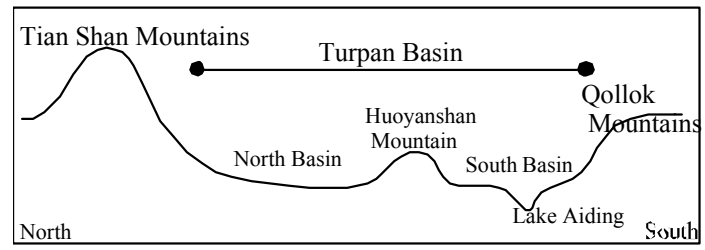

Figure 2: Cross section of Turpan Basin.

Twelve municipalities comprise Turpan. Between 1949 and 2003, the population grew from 67.3 thousand to 243.8 thousand and the cultivated area grew from 13.3 thousand ha to 19.3 thousand ha.

According to 2002 statistics for Xinjiang, 70.3\% of Turpan City's population was engaged in farming (171.5 thousand out of a population of 243.8 thousand), indicating that agriculture is the key industry. The main products are wheat, cotton, grapes and gourds (Table 1) [2].

Vineyards in Turpan City account for $45.2 \%$ of the cultivated area, and grapes account for more than half of a farming household's income. Since the climate favors long-staple cotton, cotton is produced on 4,900 ha of land, or $17.7 \%$ of the total area under cultivation. Gourds are one of the local specialties and their fields were drastically expanded from 386.7 ha in 1995 to 1,146 ha in 2002.

This study was conducted by interviews with officials at the Turpan Water Management Bureau, fieldwork, and a review of the literature.

Table 1: $\quad$ Crop types and irrigation water supply.

\begin{tabular}{|c|c|c|c|c|c|c|c|}
\hline crop type & grain crops & grape & cotton & vegetables & melon & others & total \\
\hline area (ha) & 6380 & 12486 & 4900 & 1393 & 1146 & 1353 & 27658 \\
\hline ratio (\%) & 23.1 & 45.2 & 17.7 & 5.0 & 4.1 & 4.9 & 100.0 \\
\hline $\begin{array}{l}\text { duty of Irrigation water } \\
\qquad\left(\mathrm{mm} \cdot \mathrm{y}^{-1}\right)\end{array}$ & 720 & 1200 & 825 & 1395 & 1095 & 600 & \\
\hline $\begin{array}{l}\text { total irrigation water } \\
\left(\text { million } \mathrm{m}^{3} \cdot \mathrm{y}^{-1}\right)\end{array}$ & 0.46 & 1.50 & 0.41 & 0.19 & 0.13 & 0.08 & 2.77 \\
\hline ratio (\%) & 16.6 & 54.2 & 14.8 & 6.9 & 4.6 & 2.9 & 100.0 \\
\hline
\end{tabular}

\section{Results}

\subsection{Hydrology}

The highest and lowest temperatures ever recorded at Turpan City are $47.6{ }^{\circ} \mathrm{C}$ and $-28{ }^{\circ} \mathrm{C}$. The average temperature in July is $33{ }^{\circ} \mathrm{C}$, with a large daily temperature range, and the average temperature in January is $-10{ }^{\circ} \mathrm{C}$. The annual 
average temperature is fairly high, exceeding $14{ }^{\circ} \mathrm{C}$. The region is arid, with annual average rainfall of only $16.2 \mathrm{~mm}$ and a far greater annual evaporation potential of $2,838 \mathrm{~mm}$.

Although Turpan City receives little rain, the Tian Shan Mountains receive $500-800 \mathrm{~mm}$ per year, and high peaks in the mountains are covered with glaciers. Rainfall in the Tian Shan Mountains and glacial meltwater are the major water sources of rivers.

The rivers in Turpan City are grouped into either the Tian Shan river system or the Huoyan Shan river system, depending on their origins. The Tian Shan river system includes five rivers that originate in rainfall, ice and snowmelt, and springs in the Tian Shan Mountains. These five rivers have a catchment area of $1,949 \mathrm{~km}^{2}$, an annual average discharge of 336 million $\mathrm{m}^{3}$ and an annual average flow rate of $9.38 \mathrm{~m}^{3} / \mathrm{s}$.

The Huoyan Shan river system originates in underground water that is recharged from the Tian Shan Mountains and blocked by the Huoyan Shan Mountains at the center of the basin (Figure 2). Such blocked underground water surfaces as springs that form rivers. Soon after they flow into the southern part of the basin, they subside to become underground water. The annual discharge of the Huoyanshan river system is 166.4 million $\mathrm{m}^{3}$, which is equivalent to nearly half the annual total discharge of the Tian Shan river system.

Surface water in Turpan City averages only $19,690 \mathrm{~m}^{3} / \mathrm{km}^{2}$. This is considerably less than the average for China, which is $270,800 \mathrm{~m}^{3} / \mathrm{km}^{2}$. Thus, Turpan has one of the highest demands for water in China.

\subsection{Irrigated agriculture}

The irrigation system in the Turpan Basin integrates the traditional Kareez and spring irrigation that draws from the Huoyan Shan river system with canals and reservoirs that draw from the Tian Shan Mountains and new wells.

\subsubsection{Spring irrigation}

Irrigation agriculture in Turpan City has been operated by using springs of the Huoyan Shan Mountain as water sources. Oases that were created by spring irrigation include Lukqun, Huoyan Shan and Lake Aiding.

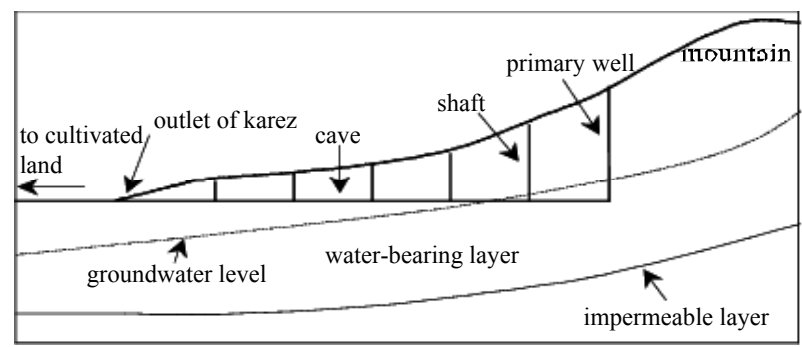

Figure 3: Structure of Kareez. 


\subsubsection{Kareez irrigation}

A Kareez is an underground aqueduct laid from mountain foothills to oases in areas to be irrigated. It is constructed by digging vertical holes at intervals of 20 to 30 meters and then connecting the bottoms of the holes by horizontal tunneling (Figure 3). A Kareez is the last part of a quanta.

\subsubsection{Irrigation using canals and wells}

With population growth and the accompanying expansion of cultivated area, the Kareez irrigation system failed to satisfy the agricultural demand. Meanwhile, the social system in Turpan changed drastically after China's Cultural Revolution and agriculture was collectivized. From around 1955, the construction of leak-proof main irrigation canals and dams started on the rivers of the Tian Shan river system. This leak prevention enabled canals to be laid in the Gobi Desert. The combined length of all canals as of 2002 was $1,971 \mathrm{~km}$, of which $748.4 \mathrm{~km}$ was leak-proof. The volume of irrigation water conducted through the canals became 203 million m3/year in 2002, accounting for $60 \%$ of the total river discharge. Moreover, seven reservoirs with a combined storage capacity of 4.90 million $\mathrm{m} 3$ were constructed. Consequently, the area irrigated by the Tian Shan river system expanded rapidly. Yet, there are great seasonal differences in the volume of available irrigation water. Usually surface water is provided from mid-May, water shortages in the seeding period of early spring created serious problems. To improve the situation, well-digging started in 1965 and wells number 1,468 today. Wells play an important role in mitigating water shortages in early spring, providing $40-50 \%$ of all irrigation water in that season.

Table 2: $\quad$ Irrigation reality in Turpan in 2002.

\begin{tabular}{c|ccc|c|c|c}
\hline water resources & water reserve & $\begin{array}{c}\text { Amount of } \\
\text { intake } \\
\left(\text { (million }^{3}\right)\end{array}$ & $\begin{array}{c}\text { Amount of } \\
\text { irrigation water } \\
(\text { million m }\end{array}$ & $\begin{array}{c}\text { propotion of each water } \\
\text { reserve to total water } \\
\text { reserve } \\
\%\end{array}$ & $\begin{array}{c}\text { irrigation } \\
\text { efficiency } \\
\%\end{array}$ & $\begin{array}{c}\text { Using rate of } \\
\text { water reserve } \\
\%\end{array}$ \\
\hline \hline River & 3.365 & 2.031 & 0.914 & 34 & 45 & 27 \\
Spring & 1.664 & 1.137 & 0.692 & 26 & 61 & 42 \\
Well & 0.992 & 0.801 & 0.641 & 24 & 80 & 64 \\
Kareez & 0.818 & 0.556 & 0.429 & 16 & 77 & 52 \\
\hline \multicolumn{1}{c}{ Total } & 6.839 & 4.525 & 2.676 & 100 & \multicolumn{3}{|c}{} \\
\hline
\end{tabular}

\section{Discussion}

\subsection{Water resources}

Irrigation water in Turpan City today can be broken down by source into $34 \%$ from rivers, $26 \%$ from springs, $24 \%$ from wells and $16 \%$ from Kareez. Before 1949, Turpan City relied heavily on Kareez and springs. But after the social system underwent complete change and the People's Commune program was established with the aim of collectivizing agricultural production, the water and land resources underwent intensive development. Rezoning, reclamation, canalization, and reservoir construction were particularly active. By 1976, seven reservoirs had been completed in Turpan City, increasing the irrigated 
agricultural land area from 13.3 thousand ha to 27.7 thousand ha and the volume of irrigation water to 267 million $\mathrm{m}^{3}$. Table 3 outlines Turpan's current irrigation system.

Population growth directly leads to increased demand for agricultural products. To boost the agricultural output, the irrigated area needed to be expanded. Also, population growth brings water shortages and environmental degradation to oases. Canals and reservoirs constructed by the People's Commune after 1958 were unable to supply enough irrigation water to the expanded farmland. To supply more water, wells were dug intensively near canals. The increased uptake from these wells lowered the groundwater level and caused drying up of Kareez.

\subsection{Problems of the irrigation system}

\subsubsection{Some main problems of water resource utilization in Turpan City [4]}

4.2.1.1 Shortage of absolute quantity of water resources The annual water supply per capita in Turpan is 1.57 ton, much less than the 6.46 ton for the Xinjiang Uygur Autonomous Region as a whole and 2.63 ton for China. Water supply per hectare of cultivated land per year in Turpan is 1.38 ton. This is half the amount for other areas.

4.2.1.2 Seasonal variations in discharge of surface water resources The outflow of surface water predominates in summer. The average summer discharge between May and August accounts for $70 \%$ of the annual discharge, or for $78 \%$ of the annual discharge in the highest year. Irrigation water is in particularly short supply in early spring.

\subsubsection{Water leakage from irrigation canals under construction and from} those that are old Because there are too few distribution facilities such as water gates, the use efficiency remains only $27 \%$ for river water, $42 \%$ for spring water, $64 \%$ for well water and $52 \%$ for Kareez water.

\subsubsection{Less use of Kareez caused by increase of intake water from wells and} rivers. The number of wells has increased markedly since the 1970s, with 1,468 wells operating today. In 1949, Kareez in Turpan City numbered 592 and the irrigation water they discharged was 210 million $\mathrm{m} 3$, or $56 \%$ of the total irrigation discharge. Today, the number of Kareez has dropped to 291 and their annual irrigation discharge has fallen to 43 million $\mathrm{m} 3$, only $16 \%$ of the total annual irrigation discharge.

The collective agricultural management conducted under the People's Commune after 1949 promoted the development of farmland and water resources. Yet, Turpan's traditional Kareez irrigation system failed to support collective agriculture. The expansion of water demand led to the construction of irrigation canals and wells instead of Kareez. The rapid increase in well intake lowered the groundwater level, reducing the available volume of Kareez water. 


\subsubsection{Specific causes of decline in Kareez}

The Kareez system in Turpan has a long history. Until 1960, Turpan relied heavily on Kareez for water for agricultural production and household use. But, as the development of water supply facilities and wells increased the intake from rivers and wells, the supply for underground water was reduced and the groundwater level fell. As a result, the water volume of the Kareez declined.

4.2.2.1 Unplanned placement of wells An increase in the volume of irrigation water was triggered by the expansion of farmland. From 1965, well water was used for irrigation. Kareez were also used, but their intake was insufficient to meet the irrigation demand because rainfall is scarce in early spring. For this reason, the role of wells in agriculture production gradually increased. Because the cost for a shallow well was small, many shallow wells were constructed haphazardly. As a consequence, underground water in near-surface aquifers was pumped up in large amounts, causing the gradual reduction of groundwater level in many wells and Kareez, which eventually invited the reduction and depletion of Kareez water.

4.2.2.2 Unplanned development of water resources Since dams and irrigation canals were developed in the ground surface river system and surface water was conducted to irrigation areas by applying concrete ducts in canals, water supply to Kareez has been reduced and the groundwater level has fallen.

4.2.2.3 Unreasonable water levies As water facilities were developed with great government subsidies, water rates became very cheap. Kareez construction and maintenance are cost- and labor-intensive. As a result, the rates for Kareez water became five times those for surface water, and more than twice those for well water. For this reason, people started using the cheaper surface water and lost the motivation to build and manage Kareez.

4.2.2.4 Kareez mismanagement As various water supply facilities were constructed after 1960, the water management authorities came to delegate the management of Kareez to villages. But the villages lacked funds to maintain them.

\section{Conclusion}

Kareez have long supported agricultural and dairy production as well as household life in the Turpan basin, and thus they are referred to in this region as "givers of life." It is evident that they will continue to play an important role in Turpan. Judging from the state of water resources in Turpan, there is little likelihood of successfully developing additional water resources. Effective use of the water resources that have already been developed should be given high priority and measures to economize water consumption should be reinforced. 
In 1981, when the People's Commune system was discontinued, the farmland in Turpan was allocated to farming households according to the number of family members. Larger families received more farmland. Land ownership today averages $1,613.4 \mathrm{~m}^{2}$ (2.42 Chinese acres) per person. The change in management system prompted more farming households to cultivate grapes, which brought a considerably higher profit per unit area (more than three times that for wheat), instantly producing problems in water demand. To deal with such problems, the local government restricted grape cultivation per farming household to $666.7 \mathrm{~m}^{2}$ (1 Chinese acre). Yet, as grape cultivation still accounts for more than half of the irrigation water supplied (Table 1), measures to economize water consumption are a major task.

In addition to such measures, there is a need to introduce methods for irrigation water conservation, such as appropriate maintenance procedures for leakage prevention, proper and voluntary water management by farmers, and development and dissemination of efficient irrigation techniques.

The Kareez is a water supply system that is designed to achieve efficiency in a harsh natural environment. Its merits include energy saving owing to natural inflow, stable water volume, rotational use, and easy water management. How to maintain such an efficient water supply system, one that is part of the local culture, is an important issue to be addressed in terms of tangibles and intangibles.

\section{References}

[1] Chinese natural resource library edition committee (1995), Chinese natural resources library edition- vol. Xinjiang, Chinese Environmental Science publisher, p.416.

[2] XinjiangUyghur Autonomous Region Statistic Office edited (2002), Xinjiang Statistical Yearbook, Chinese statistical publisher, p.114.

[3] Water use and water electricity survey design in Turpan prefecture, Xinjiang (1997), The report of the five rivers planning in Turpan prefecture Xinjiang Uyghur Autonomous, pp.1-12, inedited.

[4] Xinjiang Uyghur Autonomous Region Economic Leads the group and XinjiangUyghur Autonomous Region Statistic Office edited (1997), Social Economic of Developing cities in Xinjiang, Xinjiang public publisher, p.108. 